\title{
The Rise of Cats and Madness: II. The Seventeenth and Eighteenth Centuries
}

\subsection{The Continuing Persecution of Cats}

Seventeenth-century England witnessed an increasing interest in pet keeping, initially confined to the aristocracy but later extending to the expanding middle class. The keeping of cats as pets was still unusual except for a small group of intellectuals, artists, writers, and clerics. By the eighteenth century, prominent intellectuals such as Samuel Johnson and Horace Walpole were well known as cat lovers, adding respectability to this choice of pet. The seventeenth century also saw a sharp rise in public interest in madness. It became a major theme of the Elizabethan and Jacobean stage. Bethlem Hospital became an increasing magnet for visitors, and the number of psychiatric beds, both public and private, began to rapidly increase. By the mideighteenth century, Bethlem was widely regarded as a human zoo, attracting up to 19,000 visitors annually to observe its 200 mad inmates. For many writers, such as Jonathan Swift, madness became a dominant theme, and an unusual number of poets, who had pioneered the keeping of cats as pets, were themselves experiencing madness. By the end of the century, madness had become known as "the English malady," and it was being widely debated whether madness was increasing.

The seventeenth century was not kind to the people of England. During one 24-year period, from 1642 to 1666, the English Civil Wars were fought with upward of 200,000 casualties from fighting and disease; King Charles I was convicted of treason and beheaded; another visitation of plague killed an estimated 100,000 people in London, almost a quarter of the population; and the Great Fire of London destroyed 70,000 of the 80,000 homes in the central city.

The seventeenth century was also not kind to the cats of England or to their owners, some of whom were thought to be witches. Between 1565, when the first major witchcraft trial took place in England, and 1716, when Mary Hicks and her 9-yearold daughter were convicted of witchcraft, it has been estimated that approximately 500 witches were condemned to death. In many cases the evidence against the accused, two thirds of whom were elderly women, included that she had a special relationship with an animal called a "familiar". Cats were most commonly cited 
although dogs, birds, toads, and other animals could also be "familiars". In his book on witchcraft trials in Europe, Geoffrey Scarre claimed that accusations of the use of cats and other familiars were more common in England than in other parts of Europe [1].

From a feline point of view, the century started very badly. Following the 1603 death of Queen Elizabeth, the last of the Tudors, James I was appointed king of England. As the king of Scotland, James had been convinced that witches had tried to kill him, and in 1597 he had published a book on Daemonology, emphasizing the dangers of witchcraft. Included in the book was an account of a 1590 trial in which an accused witch had confessed to having sacrificed a cat in her effort to kill the king. Thus, when James I took the throne in England, he changed a 1563 law and made witchcraft punishable by death [2].

A century of witch-hunting ensued. One of the first major trials took place in 1612 at Pendle Hill in Lancaster where ten women and two men were accused of murdering ten people by witchcraft. One of the accused died in prison, one was found not guilty, and the other ten were executed by hanging. Such trials peaked in 1644-1646 in East Anglia where Matthew Hopkins appointed himself as "witch finder general" and went from town to town, identifying the local witches for a fee. He is thought to have been responsible for the deaths of as many as 300 women [3].

During these same years, cats continued to be persecuted because of their connection to Satan. For example, on New Year's Day in 1638 in the Ely Cathedral, "there was a great noise and disturbance near the choir occasioned by the roasting of a live cat tied to a spit...in the presence of a large and boisterous crowd". Later in the century, when anti-Catholic sentiment had become widespread, "it was the practice to stuff the burning effigies [of the Pope] with live cats so that their screams might add dramatic effect". At many county fairs, "a popular sport was that of shooting a cat suspended in a basket" [4].

\subsection{Pet Keeping Becomes More Popular}

At the same time as cats and witches were being persecuted in the seventeenth century, pet keeping in general was becoming more widespread. As stated by Keith Thomas in Man and the Natural World, "It was in the sixteenth and seventeenth centuries that pets seemed to have really established themselves as a normal feature of the middle-class household, especially in the towns, where animals were less likely to be functional necessitates...Pets were company for the lonely, relaxation for the tired, a compensation for the childless" [5].

The array of animals that were kept as pets was remarkably varied. Dogs were by far the most common, but in addition there were pet monkeys, tortoises, otters, rabbits, squirrels, and, on farms, pet lambs. Pet birds were especially popular and widely available in London bird markets. These included canaries, nightingales, goldfinches, larks, linnets, parrots, magpies, jackdaws, jays, thrushes, starlings, bullfinches, wrens, and cuckoos. The common characteristics of all pets that distinguished them from non-pet animals were that they were given a name, they were 
allowed in the house, and they were often taken to church. According to Thomas, "there was an official dog-whipper in almost every church and one of the main purposes of the Laudian communion rails was to keep dogs away from the alter" [6].

As pet keeping was spreading to the middle class in the seventeenth century, encouragement of the practice continued to come from the top. James I, who ruled from 1603 to 1625 , had two favorite hounds, one of which was unfortunately shot by his wife when she mistook it for a deer. The king was accused "of loving his dogs more than his subjects". Charles I (1625 to 1649) also kept many dogs, and "his wife gave birth prematurely in 1628 after being involved in a fight between large dogs". Charles II (1660-1685) had spaniels which now bear his name; they were said to overrun the palace "causing one courtier to remark, 'God save your Majesty, but God damn your dogs.'” The grand homes of the English aristocracy were similarly often overrun by dogs and other pets. In one home in 1638, it was said that "the great hall was strewn with marrow bones and swarmed with hawks, hounds, spaniels and terriers...In the parlor favored dogs lay around the hearth...By the late seventeenth century polite society was coming to despise this old way of housekeeping 'with dogs' turds and marrow-bones as ornaments in the hall." [7, 8]

In addition to royalty and the aristocracy, the English upper class also set the social standard for pet keeping. An example was Samuel Pepys, the son of a tailor, graduate of Cambridge, member of parliament, and chief secretary to the Admiralty under Charles II and James II. Pepys kept a pet monkey and a canary and admitted to being "much troubled" when the latter died. Pepys wife also had a dog, and in a 1660 entry in his famous diary, he noted one of the timeless problems of pet keeping: "So to bed, where my wife and I had some high words upon my telling her that I would fling the dog which her brother gave her out of the window if he pissed in the house anymore" $[8,9]$.

\subsection{Cats as Pets}

Despite the increasingly widespread practice of pet keeping in seventeenth century England, keeping a cat as a pet continued to be unusual. It wasn't that cats were not present; indeed, they were numerous, especially in London and smaller cities where they helped to control the mouse and rat population. This is verified by accounts of the Great Plague which describes dogs and cats dead in the streets from the disease. Also, during England's civil wars, there is an account of royalist forces being besieged in Colchester "until they were reduced to killing cats for food" [10].

The few examples of cat pet keeping at this time mostly involved aristocrats, clerics, poets, and artists. For example, Frances Teresa Stuart, a distant relative of the royal family, was said by Samuel Pepys to be the most beautiful woman he had ever seen; she had refused King Charles II's offer to become his mistress and instead married the duke of Richmond. She kept cats as pets and, just prior to her death in 1702, "bequeathed a legacy for the upkeep of her cats". Robert Herrick, a seventeenth century English poet and cleric, kept a cat as a pet along with a dog, sparrow, pet lamb, and pig, the last of which "was taught to drink beer out of a tankard". 
Similarly, in France, Antoinette Deshoulieres, a well-known seventeenth century poet at the court of Louis XIV, "wrote epistles to her friends and their cats under the name of her cat, Grisette". And Mademoiselle Dupuy, an acclaimed harpist, credited her cats with her musical success and at her death left her estate, including two houses, to her cats "with meticulous directions on how their meals were to be served". The court voided the will and awarded the estate to her relatives $[11,12]$.

But it was the artists in England who initially provided visual permission to keep a cat as a pet. The way had been paved by the Dutch school of genre painting in which cats were depicted as part of the household in scenes from everyday life. Several Dutch artists also depicted children playing with cats, including Jan Steen who painted at least four such scenes. Such scenes were still very unusual in European art. In his book Cats: The Rise of the Cat, Roger Tabor contended that, based on paintings at this time, the dog was "at least ten times more popular than the cat" [13].

Possibly inspired by the Dutch school, between 1665 and 1670, Mary Beale painted a portrait of a young girl holding a cat (Fig. 4.1). Beale was the daughter of a clergyman and was regarded as England's first successful female portrait painter. She was prominent in London intellectual circles and was personal friends with

Fig. 4.1 Mary Beale, "Portrait of a Girl with a Cat", c. 1665-1670, Oil on vellum. The inclusion of a cat in a portrait is very unusual in British art at this time. (Image courtesy of West Suffolk Heritage Service, under the Creative Commons License Attribution (CC BY-NC-ND))

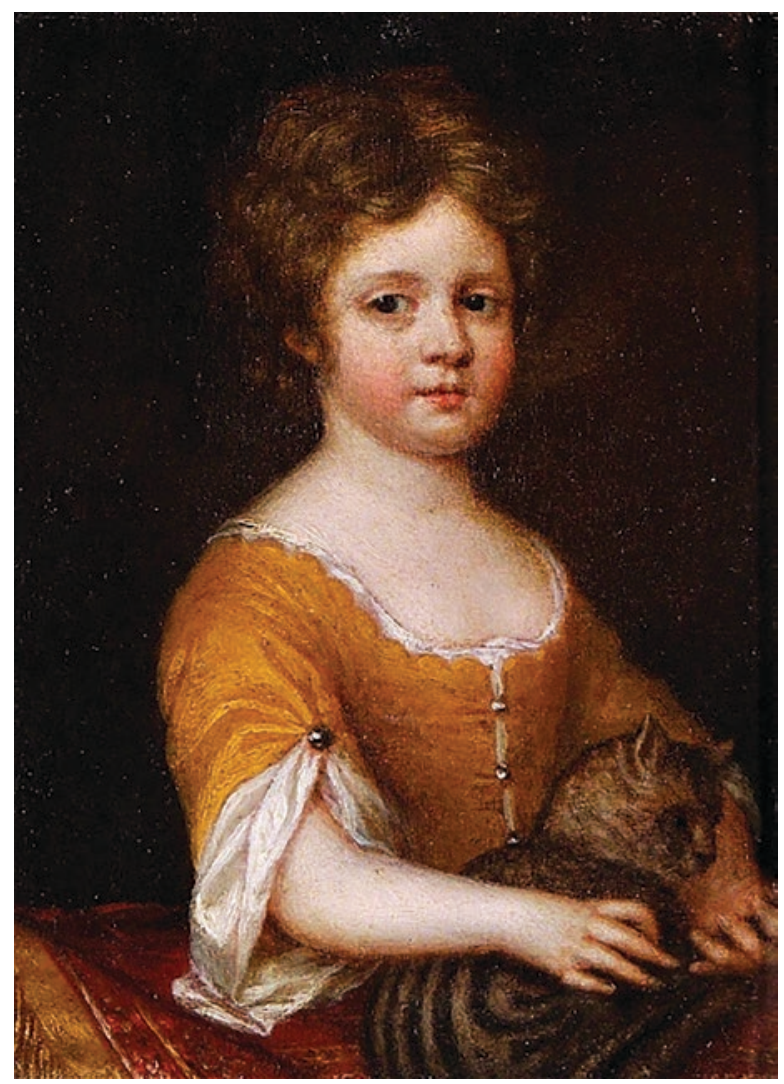


many clerics, including the archbishop of Canterbury. As art historian Caroline Bugler noted, the inclusion of a cat in a portrait is "unusual in British art of this period". What makes it even more unusual was that Mary Beale had grown up in Suffolk in East Anglia and would have been a teenager during the East Anglia witch trials of 1644-1646. She certainly would have been aware of the common beliefs about cats. The fact that she chose to ignore them and depict a cat as an appropriate pet for a young child was certainly unusual but a harbinger of things to come [14].

\subsection{Increasing Interest in Madness}

The early years of the seventeenth century in England witnessed a striking increase in the public's interest in madness. The earliest manifestations had been seen in the closing years of the sixteenth century as beggars from Bethlem Hospital appeared on the streets, as discussed in the previous chapter. According to Michael MacDonald in Mystical Bedlam, "During the late sixteenth and early seventeenth centuries, the English people became more concerned about the prevalence of madness, gloom and self-murder than they had ever been before and the reading public developed a strong fascination with classical medical psychology...Interest in insanity quickened about 1580, and madmen, melancholics, and suicides became familiar literary types. Scientific writers popularized medical lore about melancholy and clergymen wrote treatises about consoling the troubled in mind" [15].

The increasing interest in madness in sixteenth-century England was perhaps most clearly in evidence on the Elizabethan and Jacobean stage. Newly opened London theatres, such as the Curtain, Rose, and Globe, attracted a thousand or more patrons each afternoon who, for a penny admission, were entertained by the latest productions. As Thomas Dalby noted in a detailed analysis of this period, "the depiction of madness was ubiquitous during plays of this time". Similarly in The History of Bethlem, Jonathan Andrews et al. observed: "For some reason, the first quarter of the seventeenth century was a period in which playwrights seem first to have 'discovered' Bethlem as a dramatic resource". And in Mystical Bedlam, Michael MacDonald claimed that "the Jacobean stage teemed with idiots and lunatics" [16-18].

William Shakespeare (1564-1616) is of course the best known of these playwrights. According to Dalby, "in at least 20 of his 38 plays (and many of his sonnets) he comments on the nature of madness and its causes". The title character of Hamlet, written in 1601, has received extensive psychiatric analysis; Joseph Collins suggested that "the mentality of the latter [Hamlet] has probably occupied more printed space than that of any other person, real or imaginary". Opinions regarding whether Hamlet was feigning insanity or was truly insane have been approximately evenly divided, with many prominent psychiatric professionals having written on the subject. King Lear has also elicited considerable professional interest, both for the apparent dementia in the 80-year-old king and for the feigned madness of Edgar when he disguises himself as a mad Tom O’Beldam [19]. 
Other Elizabethan and Jacobean playwrights who used madness prominently include the following:

- Robert Greene (1558-1592): In The History of Orlando Furioso, a man becomes mad, kills a king, and later recovers his sanity after being treated by a witch.

- Thomas Kyd (1558-1594): In The Spanish Tragedy, which was very popular at the time, a man and his wife both become mad when they learn that their son is dead.

- Christopher Marlowe (1564-1593): In Tamburlaine, a woman becomes mad when she discovers that her husband has killed himself.

- Thomas Dekker (1572-1632): In The Honest Whore, one scene is set in Bethlem Hospital and introduces three madmen. In Match Me in London, a woman feigns madness.

- Ben Johnson (1572-1637): In Bartholomew Fair, a woman is told that she must marry a madman so she visits Bethlem to assess prospective husbands.

- John Fletcher (1579-1625): In The Mad Lover, a man becomes mad when he is rejected by a woman but regains his sanity when she later marries him. In The Two Noble Kinsmen, a woman becomes mad. In The Pilgrim some of the play is set in Bethlem.

- John Webster (1580-1634): In The Duchess of Malfi, a man attempts to drive his sister mad by having her watch madmen. Instead the man himself later becomes mad. Northward Ho, written with Thomas Dekker, includes a scene set in Bethlem.

- Thomas Middleton (1580-1627): In The Changeling, one scene is set in a private madhouse, and the doctor running it is also said to be mad.

- Philip Massinger (1583-1640): In A Very Woman, a man and his lover both become mad. In A New Way to Pay Old Debts, a man becomes mad and is treated by doctors from Bethlem.

- John Ford (1586-1640): In Broken Heart, a woman becomes mad, and in The Lover's Melancholy, a man becomes mad.

This outpouring of mad characters in the plays of the late Elizabethan and Jacobean period is remarkable and was without precedent at the time. What might explain it? In The History of Bethlem, Andrews et al. suggested a possible explanation for the prominence of Bethlem Hospital in these plays. Two of the theaters in which the plays were being featured were physically located close to Bethlem Hospital as well as to the Artillery Gardens, where fireworks were shown, and to the Tower of London. Thus visitors to Bethlem would be likely to also be interested in plays about madness, forming "a natural extension to the round of pleasure". Another explanation was suggested by Robert Reed in his book Bedlam on the Jacobean Stage. "The antics of mad folk, if embellished, were particularly suitable to the stage" claimed Reed. In short, madness made good theater [20, 21].

Perhaps the simplest explanation is that madness was a prominent theme in the plays at that time because it was of great interest to the public. The playwrights and theatres were very competitive and tended to cater to the interest of their audience. As 
noted above, the public's interest in madness significantly increased in the latter part of the sixteenth century. It seemed to some people that madness was increasing, an idea expressed in several plays. For example, in The Honest Whore, the sweeper at Bethlem Hospital claimed that "if all the mad folk...should come hither, there would not be left ten men in the city". Shakespeare also expressed this idea in Act V of Hamlet:

- Hamlet: How long has thou been a grave maker?

- First Clown: Of all the days in the year, I came to't that day that our last king Hamlet overcame Fortinbras.

- Hamlet: How long is that since?

- First Clown:...it was the very day that young Hamlet was born; he that is mad, and sent into England.

- Hamlet: Ay, marry, why was he sent into England?

- First Clown: Why, because he was mad; he shall recover his wits there; or, if he do not, "tis no great matter there.

- Hamlet: Why?

- First Clown: Twill not be seen in him there; there the men are as mad as he.

Subsequent events would support this idea.

\subsection{Bethlem as a Human Zoo}

The plays of the late Elizabethan and Jacobean period suggest that by the early 1600 s Bethlem had become well known in London. This is confirmed by a 1610 account of a visit by Lord Henry Percy, 9th earl of Northumberland, who "saw the lions, the shew of Bethlem... and the fireworks of the Artillery Gardens". The lions were being exhibited at the Tower of London, the city's first zoo. According to Michael DePorte's Nightmares and Hobbyhorses, at this time Bethlem "was commonly regarded less as a hospital than as a kind of zoo, with a fine, permanent exhibition of human curiosities". In addition to usually being able to observe mad people, visitors to Bethlem could listen to "cryings, screechings, roarings, brawlings, shakings of chains, swearings, frettings, [and] chaffings". As summarized by Edward O'Donoghue in his history of Bethlem Hospital, "Everybody who lived in London or ever came to London visited Bethlem as a matter of course" [22-25].

At the beginning of the seventeenth century, when regular visits to Bethlem began, the hospital only had 21 patients. By 1632 this number had increased to 27 patients and by 1642 to 44 as London's population increased. Mid-century visitors included the two most prominent diarists of their era; John Evelyn went out of curiosity to see something "extraordinary," and Samuel Pepys took his cousin's children who were visiting from Cambridge. By this time problems associated with visiting had apparently gotten out of control, so the hospitals' governors implemented restrictions on Sunday visiting, restricted the length of visits, and decreed that "noe Lunaticker that lyeth naked...[can] be seene by any [visitor]...without the Consent of the Physician". Such rules were largely ignored [26, 27]. 
By the 1670s Bethlem had become severely overcrowded. The hospital governors therefore agreed to build a new hospital to accommodate 120 patients since the present hospital was said to be "very old weak and ruinous and too small and straight for keeping the greater number of Lunatiker as are therein at present and more are often needful to be sent thither". The new hospital, opened in 1676, was a magnificent building modeled on French architectural principles and widely referred to as a palace for lunatics. Some people even speculated that the building was so attractive that it "might encourage exaltation and make everybody half mad-in order to be a lodger there" $[28,29]$.

The new building made the visitor-associated problems even worse since visitors now wished to come to see the building as well as the mad people. A year after the new hospital opened, a report of the hospital's governors noted "persistent complaints of prostitutes and thieves infiltrating the ranks of visitors" as well as visitors getting patients drunk "while hucksters hawked Nutts Cake [and] fruite to the patients and visitors, contributing to the fairground atmosphere". Four years later the governors noted "the greate quantity of persons that come daily to see the said Lunatikes". Representative was James Yonge, a visitor from Plymouth, who came to see "all that was curious in London" [30].

One way in which Bethlem's governors tried to prevent overcrowding was to restrict admissions to patients thought to be curable. Thus no patients with mental retardation or who had been mentally ill for a long period of time were admitted. Admissions were accepted for a period of up to 1 year, and, if the patients had not improved by that time, most were discharged as incurable. Thus there were very few long stay patients at Bethlem until new wings were added for such patients in the eighteenth century [31].

Among the better-known patients in Bethlem at this time were James Carkesse and Nathaniel Lee. Carkesse had graduated from Oxford, was a fellow of the Royal Society, and had worked under Samuel Pepys in the naval office. He then became delusional, believing himself to be the victim of a plot, and was hospitalized. He is remembered today for the poetry he wrote while confined and that was later published. He insisted that he was not mad but rather that his poetic genius was being mistaken for madness. Nathaniel Lee had been a leading English playwright and poet before becoming mentally ill. Famously, he described his hospitalization as follows: "They called me mad, and I called them mad, and damn them, they outvoted me" [32-34].

By the closing years of the seventeenth century, voices began to be raised against using Bethlem as a human freakshow. For example, in 1689, Thomas Tyron called for the closing of Bethlem to visitors. He argued that it was "a very Undecent, Inhumane thing" for the governors of the hospital "to make... a Show of those Unhappy Objects of Charity committed to their care (by exposing them, and naked too perhaps of either Sex) to the Idle Curiosity of every vain Boy, petulant Wench, or Drunken Companion". Tyron also claimed that many people regarded as sane in England were in fact behaving in ways that were just as "mad" as the inmates of Bethlem: 
"Is it worse for men to sit playing with straws than to become drunkards who "swallow down vast Estates at their Throats, and Piss away the Labours of their Ancestors against the Wall"? What then is the world, he asks, but "a great Bedlam, where those that are more mad lock up those that are less"?

It would be almost a century before Tyron's suggestion of closing Bethlem to visitors would be taken seriously [35].

\subsection{Was Madness Increasing?}

The fascination of seventeenth-century Londoners with madness was striking. First, there was an outpouring of plays featuring mad characters and Bethlem Hospital itself. That was followed by thousands of people each year visiting the hospital to observe mad people. The exhibiting of mad people was not unique to London; it was also done at the Bicetre Hospital in Paris and at the Pennsylvania Hospital in Philadelphia, the latter having been influenced by Bethlem. But at no other place in the world was there a fascination with madness at this time such as there was in England. As Michael MacDonald summarized it, "Madness was on men's lips in the seventeenth century" [36].

Another indication of the interest in mental illness in seventeenth-century England was the enthusiastic reception for Robert Burton's The Anatomy of Melancholy. Burton, a clergyman and scholar, first published the 900 page book in 1621 and then republished it four more times over the next 17 years. By "melancholy" Burton included not only depression but virtually all other forms of mental illness except violent madness. At this time melancholy was widely understood to be "the first stage of madness". Burton himself emphasized the diversity of symptoms of melancholy: "The tower of Babel never yielded such confusion of tongues as the chaos of melancholy doth variety of symptoms... The character of a melancholy man is more changeable than Proteus". Elsewhere Burton claimed that "madness is simply melancholy turned violent". Burton's book would remain popular for two centuries and was a favorite of Samuel Johnson [37, 38].

It was also at this time that the first comprehensive treatise on suicide was published. In 1630 William Gouge, a Puritan cleric, claimed that suicide was on the increase:

I suppose that scarce an age since the beginning of the world hath afforded more examples of this desperate inhumanity, than this our present age; and that of all sorts of people, clergy, laity, learned, unlearned, noble, mean, rich, poor, free, bond, male, female, young and old. It is therefore high time that the danger of this desperate, devilish and damnable practice be plainly and fully set out [39].

The seventeenth century also witnessed an increasing need for psychiatric hospital beds in England. Previously most people suffering from madness had been able to be kept at home or boarded out to a family that was paid for the service by local 
authorities. Such arrangements no longer seemed sufficient. In London in 1600, when the city's population was approximately 200,000, Bethlem Hospital had 21 beds. In 1676 the city's population was about 500,000 when the new hospital opened with 120 beds. Thus the supply of psychiatric beds was increasing much faster than the population.

Additional psychiatric beds were made available by the opening of private madhouses, especially in London. According to Michael MacDonald's Mystical Bedlam, "Beginning about 1660 scores of entrepreneurs founded private madhouses to care for the insane". Private madhouses were also being opened elsewhere in Europe at this time, especially in France, "yet nowhere did they appear in such profusion as in England or play such a dominant role". Such facilities varied in size and were completely unregulated until the end of the eighteenth century [40, 41].

Some of the private madhouses were owned and operated by physicians, others by clerics or other laypersons. For example, Thomas Allen, a physician at Bethlem, also ran a private madhouse at Finsbury. James Carkesse, who had been a patient at Bethlem, was later hospitalized at Dr. Allen's madhouse. John Ashbourne, an Anglican minister, ran a private madhouse in Suffolk, and "in 1661 he was slain by one of his charges". Conditions in these facilities were often marginal, as demonstrated by Dr. Allen giving James Carkesse a cat to control the mice and rats in his cell $[42,43]$.

The one thing that all the private madhouses offered was privacy. No records or reports were kept so cases of madness could be discretely hidden away by a family, in contrast to Bethlem where visitors could see them. One consequence of this privacy is that we have no data on how many mad people were so hospitalized or what their diagnoses were. We know, for example, that by 1724 there were 15 private madhouses in London alone, but we don't know how many patients were in each. Therefore, assessing the true prevalence of madness at this time is very difficult [44].

In summary, in seventeenth-century England, pet keeping became more common, with a few people even keeping cats as pets despite the ongoing persecution of witches. There was also a significant increased interest in madness and need for more psychiatric beds, especially in London. Was this an aberration or a trend? The eighteenth century would answer this question.

\subsection{Cats in Eighteenth Century England}

In Man and the Natural World, Keith Thomas observed that "in the eighteenth century the domestic cat established itself as a creature to be cosseted and cherished for its companionship". There were several reasons for this. One, according to Thomas, was that "the cat gained in popularity as standards of domestic cleanliness rose" since cats are perpetually cleaning themselves. Another reason was the arrival of the brown (also called gray) rat in Europe. Until the seventeenth century, Europe had been inhabited by only the black rat. However, the brown rat was stronger, multiplied more rapidly, and was more difficult to control. By the eighteenth century, the 
brown rat had established itself in England and was spreading across Northern Europe. The value of cats for rat control became much more important as "many administrative authorities began to set aside a special budget for the breeding and maintenance of ratting cats in museums, libraries, prisons, barracks, warehouses and stores" $[45,46]$.

Yet another reason for the elevated status of cats in the eighteenth century was the expansion of the English economy and growth of the middle class. As the economy improved, so did the number of merchants, shopkeepers, tradesmen, clerks, and skilled craftsmen, often with money to spare. There was said to be "an almost frenzied propensity to consume," especially novel products that were being introduced from England's overseas territories. The imports included new and improved varieties of sheep, cattle, horses, pigs, dogs, and even cats, such as the exotic longhaired Angora cat which was imported from Turkey. The rising middle class also aspired to be like the upper class which, as described previously, had set the standards for pet keeping [47].

Perhaps the most important reason for the enhanced status of cats in eighteenthcentury England was the decline in belief in witchcraft, especially among the educated class. In 1711 Joseph Addison published an essay in the Spectator ridiculing witchcraft "as a medieval superstition". Implicitly this helped to sever the popular association between cats and witches. It is even possible that some educated people then began to keep cats as a badge of their sophisticated status. Among the uneducated, however, the belief in witches died more slowly. The last witches to be tried in England were Jane Wenham in 1712 in Hertfordshire and Mary Hicks and her 9-year-old daughter in 1716 in Huntingdon. Wenham was convicted by a jury, but the clearly skeptical judge set aside her conviction and released her. During her trial one of her accusers had claimed that Jane Wenham could fly, and the judge had observed that there was no law against flying. Mary Hicks and her daughter, however, did not fare as well; they were both convicted of witchcraft and hung. Finally, in 1735 the witch-finding era in England came to an official end with the passing by parliament of the Witchcraft Act; this made it a crime to accuse anyone of witchcraft with a penalty of up to 1-year imprisonment [48, 49].

The increasing popularity of cats as pets in the eighteenth century, however, was specific to certain groups of people. According to Kathleen Kete's The Beast in the Boudoir, "the cat was linked rather with bohemia" - artists, poets, writers, and other intellectuals. "The companionship of a like-minded animal became a trope of intellectuals, the cat a sign for the literary life". In England, as in France, "a pronounced taste for cats in certain people was an indication of superior merit". Francois-Rene Chateaubriand, a French historian and politician, stated it as follows: "What I like about the cat is his character, independent and almost heartless, which prevents him from attaching himself to anyone... The cat lives alone, he has no need of society" [50].

Although bohemians and intellectuals were embracing the cat at this time, the embrace did not extend to the lower class. Georges-Louis Buffon's popular book on natural history, translated into English in 1785, characterized cats as "cruel and 
rapacious animals...they are all destructive, ferocious and untamable". The persecution of cats also continued; this is illustrated by Williams Hogarth's 1751 engravings on "The Four Stages of Cruelty" in which several boys are depicted torturing cats, including throwing one out of a window. In France at this time, the Great Cat Massacre took place in which young apprentices in a print shop, tired of seeing their master treat his cat better than themselves, beat to death the master's cat and all the other cats in the neighborhood [51].

\subsection{Cats in Art and Poetry}

The evolving eighteenth-century attitude toward cats is also illustrated by their place in art and poetry. Art historian Caroline Bugler noted that "the eighteenth century witnessed a growing tenderness towards the cat in literature and art, as befitted an age of sensibility... This era saw an increased awareness of childhood as a blessed age of innocence, so cats became the accessory of choice in portraits of children, especially young girls". Bugler added: "And just as cats came increasingly to be seen as the natural companions for young children, so they gradually migrated into adult portraits of women, where their grace and mystery could complement the sensuality of the sitter" [52].

Two of the most famous English painters of this era-William Hogarth and Thomas Gainsborough - painted children with cats. Hogarth included a cat in his 1742 painting of "The Graham Children". He also included a cat standing next to a prostitute in his painting of "A Harlot's Progress". Gainsborough's 1781 painting of "Miss Brummell" suggested that cats were appropriate companions for young girls. He also painted "The Artists Daughter's With a Cat" and "Six Sketches of Cats." Paintings of children with cats had been rare in seventeenth-century English art but became much more common in the eighteenth century. Cats became the rightful playthings of young girls, as illustrated in Joseph Wright's 1770 painting of "Two Girls Dressing a Kitten by Candlelight”. In other paintings, such as Johann Zoffrey's 1780 "Portrait of Sophia Dumergue," the daughter of an eminent London surgeon, the cat appears to emphasize her femininity (Fig. 4.2).

Given the increasing association of cats with children, it is not surprising that it was at this time that "Puss in Boots" appeared as a children's story. It is a fairy tale about how a cat used trickery to help his penniless master win the hand of a princess and live happily ever after. The story was translated from French into English in 1729 , and the original edition depicted an old woman telling the story to a group of children with a placard inscribed "Mother Goose's Tales". The story was then adapted in 1812 by the Brothers Grimm, thereby confirming cats as respectable playthings for children.

Several prominent people in England's intellectual and arts community kept cats as pets in the eighteenth century. John Rich, an actor and theater manager who opened theaters at Lincoln Inn Fields in 1714 and Covent Garden in 1732, was said 
Fig. 4.2 Johann Zoffany, "Portrait of Sophie Dumergue", c. 1780. Oil on panel. The cat is apparently included to emphasize her femininity. Sophie was about 12 at the time. (Image courtesy of Victoria Art Gallery, Bath, under the Creative Commons License (CC BY-NC-ND))

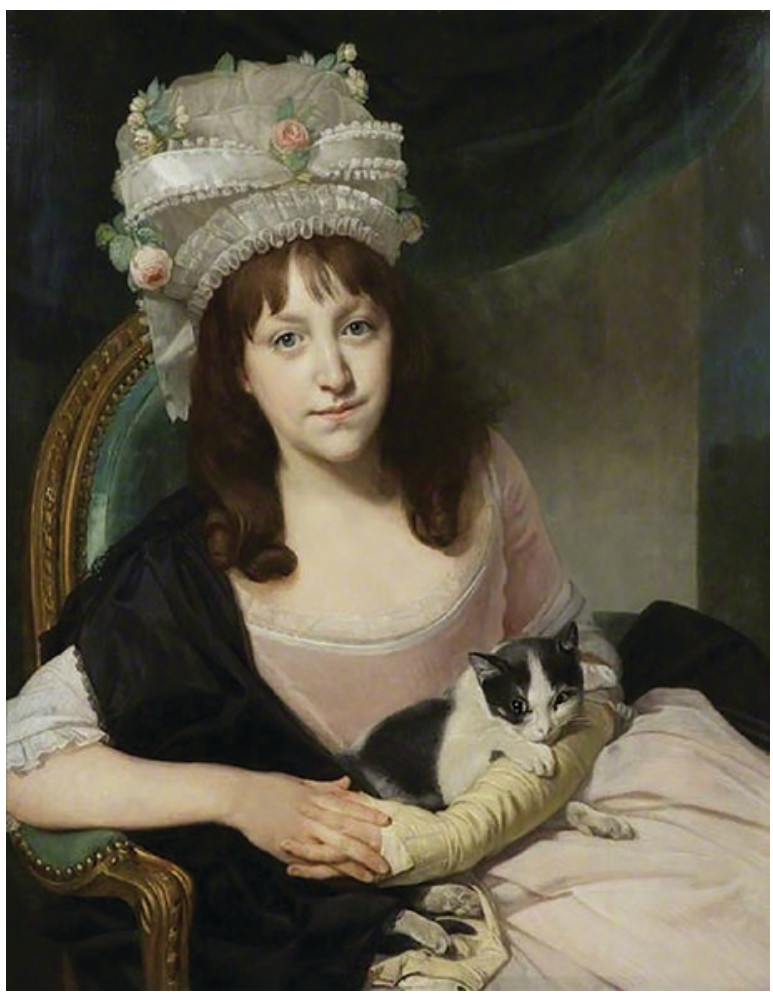

to live with "7 and 20 cats of all sizes, colors, and kinds". Samuel Johnson, generally regarded as the leading English intellectual of the eighteenth century, owned many cats. Johnson's biographer, James Boswell, described Johnson's affection for his cats:

I never shall forget the indulgence with which he treated Hodge, his cat; for whom he himself used to go out and buy oysters, lest the servants, having that trouble, should take a dislike to the poor creature. I am, unluckily, one of those who have an antipathy to a cat, so that I am uneasy when in the room with one; and I own, I frequently suffered a good deal from the presence of this same Hodge. I recollect him one day scrambling up Dr. Johnson's breast, apparently with much satisfaction, while my friend smiling and half whistling, rubbed down his back, and pulled him by the tail; and when I observed he was a fine cat, saying "why yes, Sir, but I have had cats whom I liked better than this," and then as if perceiving Hodge to be out of countenance, adding, "but he is a very fine cat, a very fine cat indeed". 
In 1778 Hodge was immortalized by poet Percival Stockdale in "An Elegy on the Death of Dr. Johnson's Favourite Cat". Today a statue of Hodge sits outside the house where Samuel Johnson lived in London, and the cat has its own entry on Wikipedia [53, 54].

William Stukely was another intellectual of this period who enjoyed cats. Physician, clergyman, and archeologist, Stukely was a fellow of the Royal Society and pioneered the archeological investigations of Stonehenge and Avebury. In 1745 he memorialized his cat, noting that it had given him "much pleasure, without trouble" and relating the cat's "inimitable ways of testifying her love to her master and mistress". Essayist and politician Sir Richard Steele also liked cats; in an essay in The Tatler, he described the narrator coming home to his little dog and cat who welcome him "each of "em in his proper Language" [55].

Horace Walpole was another leading eighteenth-century intellectual who was very fond of cats. The son of a British prime minister, Walpole was a novelist, prominent letter writer, and member of parliament. He owned at least two cats, one of which was immortalized in 1747 by the poet Thomas Gray. Gray, who was Walpole's closet friend and known as "the most learned man in Europe," wrote the poem for Walpole after one of his cats drowned in a large china tub filled with goldfish. In a letter accompanying the poem, Gray conveyed his own considerable affection for cats. The poem, titled "Ode on the Death of a Favourite Cat Drowned in a Tub of Goldfishes," opened with the cat sitting at the edge of the tub gazing wistfully at the fish. The oft-quoted denouement was inevitable:

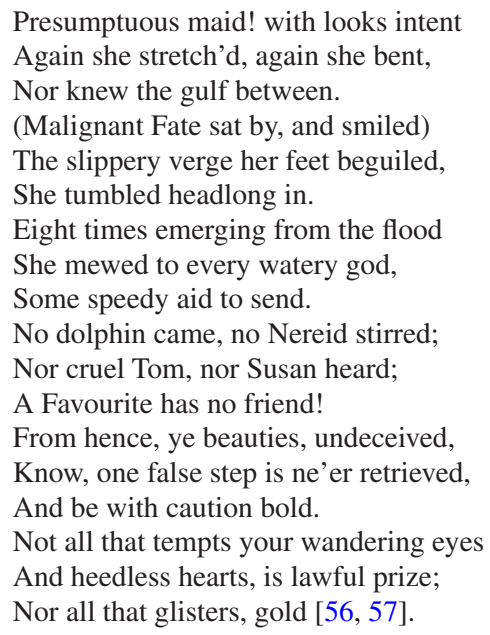

Eighteenth century poets seemed to be inordinately attracted to cats, leading the French art critic who wrote under the name Champfleury to later claim that to understand cats "one must be a woman or a poet". In addition to Thomas Gray, two other prominent poets of this era who wrote poems about cats were Christopher Smart and William Cowper. Both men also suffered from periods of severe madness [58]. 
Christopher Smart, born in 1722, was initially regarded as one of the most promising poets of his generation. At Cambridge he was named the "scholar of the university" and later taught philosophy and rhetoric there. Moving to London, he went to work for the publisher Thomas Newberry and married Newberry's stepdaughter. His early poetry was well regarded by Samuel Johnson and others and won the Cambridge Seaton poetry prize five times in 6 years. The two poems for which Smart is best known are "A Song to David" and "Jubilate Agno"; the latter was incorporated into a cantata by composer Benjamin Britten.

It was during a period of psychiatric hospitalization that Smart wrote both of these poems. "Jubilate Agno" includes sections reflecting frankly psychotic thinking, including a "fascination with alphabetic sequence puns, word plays, sheer sound, and its relentless reiteration". Among cat lovers the best-known part of the poem is a long passage in which Smart praises his cat, Jeoffry:

For I will consider my Cat Jeoffry.

For he is the servant of the Living God duly and daily serving him.

For at the first glance of the glory of God in the East he worships in his way.

For this is done by wreathing his body seven times round with elegant quickness. For then

he leaps up to catch the musk, which is the blessing of God upon his prayer.

Smart even claimed that his cat stood in opposition to the Devil, a surprising claim in an era when cats were still being persecuted because of their association with dark powers.

For when his day's work is done his business more properly begins.

For he keeps the Lord's watch in the night against the adversary.

For he counteracts the powers of darkness by his electrical skin and glaring eyes.

For he counteracts the Devil, who is death, by brisking about the life.

For in his morning orisons he loves the sun and the sun loves him.

For he is of the tribe of Tiger [57].

William Cowper, born in 1731, was said to have been "one of the most eminent poets of his time". William Wordsworth regarded Cowper as "the only poet whom he thought worthwhile learning off-by-heart". Cowper was especially fond of animals, including cats, and at one time was said to have also kept "two dogs, two goldfinches, two canaries, five rabbits, three hares, two guinea pigs, a squirrel, a magpie, a jay, and a starling". He was also a prolific letter writer, often including "his adventures with Puss" [59-62].

Among Cowper's better-known poems are two about cats. In "The Retired Cat," he described his cat as "A Poet's cat, sedate and grave/as poet well could wish to have," which goes to sleep in a partially open drawer in the poet's bedroom but then the housekeeper, not seeing the cat, shuts the drawer. That night Cowper was awakened when the cat made itself known. "The Colubriad," by contrast, described three of Cowper's kittens which were confronted by a viper snake:

Close by the threshold of a door nailed fast

Three kittens sat; each kitten looked aghast;

I passing swift and inattentive by, 
At the three kittens cast a careless eye,

Not much concerned to know what they did there,

Not deeming kittens worth a poet's care.

But presently a loud and furious hiss

Caused me to stop and to exclaim, 'What's this?'

When lo! upon the threshold met my view,

With head erect, and eyes of fiery hue,

A viper, long as Count de Grasse's queue.

Forth from his head his forked tongue he throws,

Darting it full against a kitten's nose,

Who having never seen, in field or house,

The like, sat still and silent as a mouse;

Only projecting with attention due,

Her whiskered face, she asked him, 'Who are you?'

Cowper then seized a garden hoe and summarily dispatched the snake [57].

\subsection{Hospitals for Mad Persons}

At the same time as cats were becoming established as common companions for artists, writers, and other intellectuals in eighteenth-century England, madness was becoming established as an increasing problem. The beds in Bethlem Hospital were continually full despite efforts by the hospital to restrict admissions to only those most in need. In a Survey of the Cities of London and Westminster, published in 1720, John Strype noted that "those are judged the fittest Objects for this Hospital [Bethlem] that are raving and furious and...likely to do mischief to themselves or others". Specifically excluded from admission were "those that are only Melancholik...or Ideots...these the Governores think the House [Bethlem] ought not be bothered with". Similarly, in The History of Bethlem, Jonathan Andrews claimed that "Bethlem was primarily a place for keeping lunatics who were a menace to themselves or others". A study of patients admitted to Bethlem Hospital between 1772 and 1787 reported that "above one half of the patients...have attempted some mischief against themselves or others...There are above a score of atrocious murderers: there are parricides, and butchers of their own offspring". By the 1780s there were 200 patients on the waiting list for admission. For readmissions, "Nearly two-thirds were forced to wait between five and nine years for the time their petitions were read before they were readmitted" [63-67].

As pressure for admission to Bethlem's limited number of beds increased, other psychiatric hospitals, both public and private, were being built. In Norwich, one of the largest cities outside of London, Mary Chapman left funds upon her death in 1724 to endow a public hospital for "distrest lunatiks". Chapman, the daughter of one of the city's wealthiest men, had had "lunacy....afflict some of my nearest relations and kindred" and founded the hospital "as a monument of my thankfulness to God" for having "blessed me with the free use of my reason and understanding". In 1725 London bookseller and member of parliament Thomas Guy left funds in his will to create a "lunatic house" in what would be called Guy's Hospital. In 1751 
London's St. Luke's Hospital was opened by public subscription; a pamphlet entitled "Reasons for Establishing St. Luke's" noted Bethlem Hospital's overcrowding and long waiting list. In its first 10 years, St. Luke's admitted 749 patients, and by 1800 it had 300 beds, surpassing Bethlem in size. Additional psychiatric hospitals using public subscriptions were opened in 1764 in Newcastle, in 1766 in Manchester, in 1777 in York, in 1795 in Liverpool, and in 1801 in Oxford. Most of these facilities were small, with accommodations for 30 or fewer patients, but they represented a beginning for the increasing number of mentally ill individuals who were considered in need of hospitalization [68, 69].

It is noteworthy that subscribers who contributed funds for these hospitals did so specifically in response to perceived needs: for example, the founders of the Manchester Lunatic Hospital voted to raise the necessary funds for the hospital in order to provide care for "the Number of distressed Objects of this kind, with which this Kingdom unhappily abounds...no Cases could be more truly deplorable than those of Poor Lunatiks, who had in common no Prospect of a Cure and who...continued public Spectacles of the deepest Misery, if not Terror, to the Neighbors". Similarly, the Yorkshire Asylum was opened because of a belief that "something should be done for the relief of those unhappy sufferers who are the objects of terror and compassion to all around them and whose cases lay a just claim to the benevolence of their fellow creatures". According to Nigel Walker and Sarah McCabe, "an unmistakable phenomenon of this period was a growing public awareness of the special nature of the social problem posed by the mentally disordered," which showed itself "in the foundation by voluntary subscription of hospitals for the insane". Also representative of this growing public awareness was a sermon preached at St. Bridget's Church in London during Easter Week of 1759: "The Care of the Incurable Lunaticks, and the Charity Due to Them, Particularly Recommended" [70-73].

As the public psychiatric hospitals became more overcrowded in the eighteenth century, they increasingly restricted admission to the sickest and poorest patients. It thus became difficult for mentally ill individuals from upper class families to gain admission to the public hospitals, yet it was precisely the upper class that was apparently experiencing the fastest increase in madness and other nervous disorders. In response to this need for more upper-class beds, private madhouses proliferated. A few such facilities had opened in the closing years of the seventeenth century, especially in London, but during the first half of the eighteenth century, they increased rapidly in number. The problem was that there was no registration or regulation of them. Anyone could open a private madhouse, and it could be very profitable, so private madhouses were widely referred to as the trade in lunacy. Some of the private madhouses were run by respected physicians, such as William Battie who worked at the public St. Luke's Hospital as well as his own private facility, John Monro who worked at Bethlem Hospital as well as his own private facility; and Nathaniel Cotton who also wrote poetry and whose "Collegium Insanoraum" housed the poet Christopher Smart among others.

However, other private madhouses were run by individuals with no psychiatric skills, and the system was ripe for abuse. Wrongful confinement of sane persons in 
private madhouses was thematically used in several novels of the period, including Samuel Richardson's Pamela; or Virtue Rewarded (1740) and Clarissa Harlowe (1748), Tobias Smollett's The Life and Adventures of Sir Launcelot Greaves (1760), and Mary Wollstonecraft's Maria (1798). Several individuals who believed they had been wrongfully confined also published personal accounts, including Alexander Cruden (The Adventures of Alexander the Corrector, 1754) and Samuel Bruckshaw (The Case, Petition and Address of Samuel Bruckshaw, 1774). Both of these accounts include suggestions that the writers were indeed legitimately insane at the time of their involuntary confinement, despite their protestations to the contrary.

How often such private madhouse abuses actually happened in the eighteenth century is less clear. Patricia Allderidge suggested that "such cases were not frequent but were well publicized". William Parry-Jones, author of the definitive book on The Trade in Lunacy, also concluded that "despite the view that such abuses were widespread, surviving evidence for this is limited and often is based upon sensational accounts by persons of doubtful reliability". Finally in 1774, following parliamentary hearings, the Madhouses Act was passed establishing the licensing and inspection of all madhouses in London and vicinity $[74,75]$.

\subsection{Public Interest in Madness}

Perhaps the strongest evidence that madness was becoming more common in eighteenth-century England was the continuing intense public interest in the subject. In Cecil Moore's Backgrounds of English Literature 1700-1760, the author noted that "the seriousness of public interest [in mental disorders] is best reflected in letters, diaries, and other private records not intended for publication". Fiction of the period abounds with mad characters, beginning with Jonathan Swift's "Digression on Madness" in his 1704 A Tale of a Tub. English professor Michael DePorte claimed that "few writers of the eighteenth century were so morbidly fascinated by madness and madhouses as Swift". Regarding his satires, "madness is their obsessive theme; they expose and isolate one source of insanity after another and taken together they contain an alarming gallery of lunatics" [76, 77].

The theme of madness in literature continued throughout the century. The opening of Alexander Pope's narrative poem The Dunciad (1728) is set next to the walls of Bethlem. In Henry Fielding's The Intriguing Chambermaid (1733), Mr. Goodall is told that he is "a poor distracted wretch, and ought to have an apartment in a dark room, and clean straw". In Tobias Smollett's Count Fathom (1753), Elinor becomes insane and is sent to Bethlem Hospital to recover. In Laurence Sterne's Tristam Shandy (1760), Maria is also insane; the book was so popular that "Maria had inspired more than 30 paintings by the start of Victoria's reign". In Frances Sheridan's Memoirs of Miss Sidney Biddulph (1767), the protagonist is driven insane by guilt and confined to an asylum for the remainder of his life [78].

Visits to Bethlem, which had begun in the seventeenth century, intensified in the eighteenth. It was as if the public could not get enough of madness. English essayist Richard Steele took his three younger brothers "to show "em ... Bedlam" and later 
sarcastically wrote that he had consulted "the collegiates of Moorfield," the part of London where Bethlem Hospital was located. Nicholas Blundell, visiting from Lancashire in 1703, "walked to Bedlam [sic]" and on two subsequent visits to London returned to the hospital to show his wife and daughters. Bethlem was a major attraction for foreign visitors as well. Travel guides such as Les Delices de l'Angleterre (1707) and Travels in London (1710) listed Bethlem as a major attraction. A German traveler at this time was intrigued by a patient "who is said to have crowed all day long like a cock" [79].

By the 1730s, the crowds at Bethlem included England's foremost aristocrats. The prince of Wales visited in 1735, the same year in which William Hogarth painted the eighth and final scene of The Rake's Progress on a Bethlem ward, showing an insane Thomas Rakewell being looked down upon by two noble ladies. In 1741 Samuel Richardson published Familiar Letters on Important Occasions, intended to provide "the requisite style and forms" for "letters written to and for particular friends on the most important occasions." One of his model letters was "from a young Lady in Town to her Aunt in the Country Describing Bethlem Hospital": "I have this afternoon been with my cousins to gratify the odd curiosity most people have to see Bethleham [sic] or Bedlam Hospital. A more affecting scene my eyes never beheld .... For there we see man destitute of every mark of reason and wisdom, and levell'd to the brute creation, if not beneath it" $[80,81]$.

By 1742 the flow of visitors to Bethlem had become a constant stream. The hospital governing board estimated that "about 19 thousand visitors" came each year to observe the approximately two hundred patients. That same year, the hospital governing board decided to appoint the hospital porter as a constable "to prevent disturbances ....at Holiday times." The crowds continued to increase and included such individuals as a young lady in 1752 who came "down from the country" to "see the tower, the [Westminster] abbey, and Bedlam, and two or three plays". By 1764 it became necessary to assign "four constables and also four stout fellows as assistants in each gallery" because "great riots and disorders have been committed in this hospital during the holidays." Because of the continuing disorder, 2 years later Bethlem Hospital was closed to all visitors on major holidays, and in 1770 it was closed to all visitors except those who had a ticket signed by the hospital's governor $[82,83]$.

The interest in viewing the insane in eighteenth-century England was quite extraordinary. A few visitors came out of "a moral duty, painful and distressing, yet pointing useful lessons .... A sight of Bethlem might be recommended as a peculiarly effective deterrent to the wayward inclinations of children". Most visitors, however, came to see the patients as "curiosities," "remarkable characters," and "very amusing objects". It was the titillation of a freak show, of viewing exotic human specimens not previously seen. Bethlem Hospital was thus regarded as a kind of human zoo, reminiscent of public exhibitions of lions, elephants, and other exotic creatures put on display by English explorers as they returned from Africa and Asia. In Henry Mackenzie's 1771 novel The Man of Feeling, Harley, the protagonist, described a visit to Bethlem Hospital, made because it was one of "those things called Sights in London, which every stranger is supposed desirous to see." 
During the visit the hospital guide told Harley, "in the phrase of those that keep wild beasts for show," that patients in one particular ward "were much better worth seeing than any they had passed, being ten times more fierce and unmanageable." $[84,85]$

\subsection{Mad Poets}

One of the characteristics of madness in eighteenth-century England was that it appeared to affect the upper social classes, and especially writers and intellectuals, disproportionately. This is best illustrated by Kay Jamison's study of 36 poets in her book Touched with Fire. All 36 of the poets were born between 1705 and 1805 and were selected because they were prominent in " 15 anthologies of eighteenth- and nineteenth-century verse". Jamison then assessed their biographical information to ascertain how many were mentally ill. Among the 36 poets, she reported that 11 either had psychotic thinking, were confined to a psychiatric hospital, or committed suicide. She added that four others appear to have had bipolar disorder but not psychotic thinking or hospitalization. Altogether it would appear that at least one third of these poets would have been thought of as mad in the eighteenth century. And Jamison's list is not necessarily complete; it did not include Sir Charles Hanbury Williams, born in 1708, who was known as "the mad poet". As George S. Rousseau noted in 1969, "it is an ironic contrast that the supposed 'Age of Reason' should have produced so many cases of insanity among its writers" [86-88].

Christopher Smart, discussed above, was one example cited by Jamison. His psychiatric problems began in his 30s and focused on what was then called religious mania. He would suddenly drop to his knees in the middle of busy streets and insist that everyone around him join him in prayer. After several episodes of such behavior, punctuated by periods of depression, Smart was committed to newly opened St. Luke's Hospital for Lunatics where he remained for a year. Discharged as incurable, he then spent 4 more years in a private madhouse at Bethnal Green in London.

William Cowper was plagued by intermittent bouts of madness. These included auditory hallucinations, delusions that he had been dammed by God, a belief that other people could hear his thoughts, and severe depression. Cowper unsuccessfully tried on several occasions to take his own life by poison, drowning, stabbing, and hanging, and there are suggestions that he also castrated himself. He was hospitalized multiple times, including spending almost 2 years at Nathaniel Cotton's private madhouse at St. Albans. Cowper was acutely aware of his own madness and found it very unpleasant. He noted: "This of all maladies that man infect/Claims most compassion, and receives the least". And in a poem titled "Lines Written During a Period of Insanity," he wrote:

Man disavows, and Deity disowns me:

Hell might afford my miseries a shelter;

Therefore hell keeps her every hungry mouths all

Bolted against me [89-92]. 
One of Cowper's best-known poems, "The Task," described the madness of "a serving maid" whose lover dies at sea:

She heard the doleful tiding of his death-

And never smiled again! And now she roams

The dreary waste...

She begs an idle pin of all she meets,

And hoards them in her sleeve, but needful food,

Though pressed with hunger oft, or comlier clothes,

Though pinched with cold, asks never. Kate is crazed.

According to Phillip Martin, Cowper's description of Kate "was responsible for the massive popularity enjoyed by poems depicting madwomen in the magazines and miscellanies of the 1790s". Cowper's crazy Kate was also the inspiration for the numerous paintings, most notably Henry Fuseli's 1807 painting by that name, which was widely imitated. As Helen Small recently noted, "Between 1770 and about 1810 , stories about bereaved or deserted women fallen into insanity were the subject of an extraordinary vogue in sentimental prose, poetry, drama, and painting" [93, 94].

In addition to Christopher Smart and William Cowper, William Collins was another mad poet cited by Jamison. He was born in 1721, educated at Oxford, and published his first poems at age 18. He then moved to London where he met Samuel Johnson. In his Lives of the Most Eminent English Poets (1779-1781), Johnson described Collins's work as follows: "He loved fairies, genii, giants, and monsters; he delighted to rove through the meanders of enchantment, to gaze on the magnificence of golden palaces, to repose by the water-falls of Elysian gardens". At age 32, Collins was "confined in a house of lunatics" because of "that depression of mind which enchains the faculties without destroying them, and leaves reason the knowledge of right without the power of pursuing it". Johnson also noted that Collins "puts his words out of the common order, seeming to think, with some later candidates for fame, that not to write prose is certainly to write poetry". Following discharge from the madhouse, Collins lived with his sister and died at age 38 [95].

Thomas Chatterton, born in 1752, was said by Jamison to have had bipolar disorder. Regarded as one of England's most brilliant young poets, Chatterton published his first poems at age 11. At 15 he began publishing poems that he attributed to the lost writings of a fictitious fifteenth-century monk named Thomas Rowley. The poems were well regarded, and Chatterton maintained his hoax for a year until he was finally unmasked by Horace Walpole. A year later, at age 17, Chatterton killed himself by swallowing arsenic and became "an emblem for the English romantic movement". Samuel Taylor Coleridge published a "Monody on the Death of Chatterton". John Keats dedicated a poem to Chatterton, "the Most English of Poets except Shakespeare". And William Wordsworth would remember him as "the marvelous Boy, the Sleepless South that perished in his pride" [96].

At the time Chatterton took his life, suicide was on the increase in England and widely regarded as a form of madness. An article in a popular journal in 1720 claimed that "more people kill themselves in this one country [England] than in the rest of the entire world combined". In 1737 a French visitor to London was quoted 
as being astonished "to hear of such frequent self-murders [sic] as happens here almost daily". In 1743 Scottish poet Robert Blair published "The Grave" which included these lines:

Self-murder! —name it not: Our island's shame,

That makes her the reproach of neighboring states [97].

Thomas Gray was another poet who claimed that suicide in England had become "epidemical". Gray himself suffered from what he called "white Melancholy... which though it seldom laughs or dances... is a good easy sort of state". However, it sometimes became black melancholy which "excludes and shuts its eyes to the most possible hopes, and everything that is pleasurable". In two lines in his poem "Ode on a Distant Prospect of Eton College," Gray eloquently captured the contradictory feelings inherent in his melancholy:

And moody Madness laughing wild

Amid severest woe $[98,99]$.

\subsection{The English Malady}

In 1733 George Cheyne, a prominent London physician, published a widely read book titled The English Malady. Cheyne had been stimulated to write the book by his concern about suicide. He had become alarmed by the "late Frequency and daily Encrease of wanton and uncommon self-murderers, produc'd mostly by this Distemper". Cheyne focused much attention on "spleen, vapors, lowness of spirits, and hypochondriacal and hysterical distempers" which he regarded as being the less severe end of the spectrum of distempers, with "true Manias, real Lunacy [and] Madness" on the more severe end. The less severe nervous disorders were merely "a lower Degree of Lunacy, and the first Step towards a distemper'd Brain" [100, 101].

Cheyne believed that nervous disorders were especially common in England:

The Title I have chosen for this Treatise, is a Reproach universally thrown on this island by Foreigners, and all our Neighbours on the Continent, by whom nervous Distempers, Spleen, Vapours, and Lowness of Spirits', are in Derision, called the ENGLISH MALADY. And I wish there were not so good Grounds for this Reflection.

He also believed that such disorders were increasing in frequency and severity. "They were scarce known to our Ancestors, and never rising to such fatal Heights, nor afflicting such Numbers in any other known Nation". "In England alone..I have been told that a late worthy and learned Physician, that had examin'd into the Numbers confin'd for Lunacy and Madness, upon the strictest Examination, found they reach'd to a Number I dare not name". Another aspect of the nervous disorders that impressed Cheyne was that they seemed to occur most commonly among people "of the better sort". By "better sort" Cheyne meant that such disorders "seldom and I think never happens or can happen, to any but those of the liveliest and 
quickest natural Parts, whose Faculties are the brightest and most spiritual, and whose Genius is most keen and penetrating, and particularly where there is the most delicate Sensation and Taste, both of Pleasure and Pain" [102].

As one of the best-known London physicians of his era, Cheyne counted among his patients David Hume, John Wesley, Alexander Pope, and Samuel Johnson. Johnson was impressed by Cheyne and by The English Malady, and he recommended the book to James Boswell. Johnson had an intense interest in nervous disorders because of his own problems, a mixture of symptoms that today would be diagnosed as obsessive-compulsive disorder and Tourette's syndrome. For example, he regularly touched every post along the street as he walked, avoided stepping on the paving stones, and, according to Boswell, exited doorways "by a certain number of steps from a certain point, or at least so that either his right or his left foot...should constantly make the first actual movement when he came close to the door or passage". Johnson was intensely troubled by his obsessions and compulsions, believing they were a sign of impending madness. Such was his fear of going completely mad that, "as a precautionary measure, [Johnson] apparently entrusted his great friend, Mrs. Hester Thrale, with a chain and padlock, for emergency use" [103-105].

A shared interest in madness was a strong bond between Johnson and Boswell, his friend and eventual biographer. Both men had experienced periods of serious depression. Both men had visited Bethlem to observe mad people-Johnson apparently on more than one occasion and Boswell in 1771. Both men wrote about madness. Johnson did so in his 1759 Rasselas in which an astronomer becomes delusional and believes he can control the sun; Boswell did so in a series of essays he published in the London Magazine between 1777 and 1783 under the title "The Hypochodriack." Where Johnson and Boswell differed was on the relationship between madness and lesser forms of nervous disorders. Johnson, like George Cheyne, believed that the conditions were on a spectrum with madness simply being a more severe variant of melancholy or other nervous disorders. Thus Johnson was perpetually afraid that his own depression or obsessive-compulsive symptoms would slide down the spectrum into madness. Boswell, by contrast, believed that madness was fundamentally different from the other disorders. As described by him, "Dr. Johnson and I had a serious conversation by ourselves on melancholy and madness: which he was, I always thought, enormously inclined to confound together. Melancholy, like 'great wit' may be near allied to madness; but there is, in my opinion, a distinct separation between them". Boswell himself knew the difference, since "one of his own children, Euphenia, was mentally deranged," and his brother, John, was intermittently insane and confined in private asylums. On one occasion Boswell reflected on his brother's illness: "It was a curious sensation when I saw my brother, with whom I had been brought up, in such a state. Madness of every degree is inexplicable" [106, 107].

When Samuel Johnson published Rasselas in 1759, one of his characters noted: "Of all the uncertainties of our present state, the most dreadful and alarming is the uncertain continuance of reason". In fact, Johnson believed that madness was increasing in prevalence and told Boswell that it had "grown more frequent since 
smoking had gone out of fashion," since he thought smoking tranquilized the mind. In believing that madness was increasing, he was following the claim of Cheyne's The English Malady [108, 109].

As the eighteenth century progressed, others began to share Cheyne's concern. In 1735, 2 years after the publication of Cheyne's book, a letter to the Royal College of Physicians referred to madness as "epidemical" and noted: "Our nation has been observed by foreigners to abound in maniacs, more than any other upon the face of the earth...I find it has of late increased so much among us, that there is scarce a family in the nation entirely free from it". In 1750, the anonymous author of $A$ Treatise on the Dismal Effects of Low-Spiritedness claimed that the problem was "almost peculiar to, and epidemical in, this kingdom". In 1758 William Battie, one of the most respected physicians in London and who had been on the board of governors for Bethlem, called madness "a terrible and at present very frequent calamity". In 1778 William Perfect, the owner of a private madhouse, published his book on Select Cases in the Different Species of Insanity in which he claimed that "instances of insanity are at this day more numerous in this kingdom than they were at any former period". Then in 1788 William Rowley published a book on nervous disorders in women and asserted that "England, according to its size and number of inhabitants, produces and contains more insane than any other country in Europe". In the closing years of the eighteenth century, books about psychiatric disorders in general and insanity in particular proliferated rapidly. According to one study, between 1701 and 1744, 24 such books were published in England, but from 1745 to 1788 , an additional 64 such books were published [110-112].

And then the unimaginable happened. In November, 1788, King George III developed a fever and other physical symptoms. Over the next several weeks, his illness progressed to delusions, hallucinations, mania, and violent outbursts that required the use of restraints. At first the king's physicians said little publicly, but rumors circulated among the public, including a rumor that the king had died. Eventually, however, the true story came out - the king himself had become mad. Here, then, for many was a confirmation of the magnitude of the English malady.

\section{References}

1. Scarre G. Witchcraft and magic in $16^{\text {th }}$ and $17^{\text {th }}$ century Europe. London: Macmillan; 1987. p. 23.

2. Scarre G. Witchcraft and magic in 16th and 17th century Europe. London: Macmillan; 1987. See also the entries for James I and Daemonology on Wikipedia. Accessed 6 May, 2019. https://en.wikipedia.org/wiki/Daemonologie.

3. Mathew Hopkins entry on Wikipedia. https://en.wikipedia.org/wiki/Matthew_Hopkins.

4. Thomas K. Man and the natural world. New York, Oxford; 1983. p. 109-10.

5. Thomas K. Man and the natural world. New York, Oxford; 1983. p. 110, 118.

6. Thomas K. Man and the natural world. New York, Oxford; 1983. p. 112-6.

7. Thomas K. Man and the natural world. New York, Oxford; 1983. p. 102-4, 111.

8. Serpell J. In the company of animals. Oxford: Basil Blackwell; 1986. p. 40.

9. Thomas K. Man and the natural world. New York, Oxford; 1983. p. 111.

10. Zimmer C. Soul made flesh. New York: Free Press; 2004. p. 102.

11. Thomas K. Man and the natural world. New York, Oxford; 1983. p. 118. 
12. Rogers KM. Cat. London: Reaktion Books: 2006. p. 82.

13. Tabor R. Cats: The rise of the cat. London, BCA; 1991. p. 58. This ratio coincides exactly with an informal survey I did at the Louvre in Paris of all paintings there dated prior to the $18^{\text {th }}$ Century.

14. Bugler C. The Cat: 3,500 years of the cat in art. New York: Merrell; 2011. p. 204.

15. MacDonald M. Mystical bedlam, madness, anxiety and healing in seventeenth-century England. Cambridge, U.K.: Cambridge University Press; 1981. p. 2.

16. Dalby JT. Elizabethan madness: on London's stage. Psychol Rep. 1997; 81:1331-43.

17. Andrews J, et al. The History of Bethlem. London: Routledge; 1997. p. 130.

18. MacDonald M. Mystical bedlam, madness, anxiety and healing in seventeenth-century England. Cambridge, U.K.: Cambridge University Press; 1981. p. 122.

19. Collins J. Lunatics in literature. North American Review. 1923; 218:376-87.

20. Andrews J, et al. The History of Bethlem. London: Routledge; 1997. p. 132.

21. Reed RR. Bedlam on the Jacobean stage. Cambridge: Harvard University Press; 1952. p. 39.

22. Andrews J, et al. The History of Bethlem. London: Routledge; 1997. p. 167.

23. DePorte MV. Nightmares and hobby horses. San Marino: Huntington Library; 1974. p. 3.

24. Andrews J, et al. The History of Bethlem. London: Routledge; 1997. p. 51.

25. O'Donoghue E. The story of Bethlem Hospital. London: Unwin; 1914. p. 152.

26. Scull A. The most solitary of afflictions. New Haven: Yale University Press; 1993. p. 11.

27. Andrews J, et al. The History of Bethlem. London: Routledge; 1997. p. 187, 190.

28. Andrews J, et al. The History of Bethlem. London: Routledge; 1997. p. 233.

29. Leigh D. The historical development of British psychiatry, vol 1. Oxford: Pergamon; 1961. p. 3.

30. Andrews J, et al. The history of Bethlem. London: Routledge; 1997. p. 189-90, 178, 186.

31. Porter R, Manacles M-F. A history of madness in England. Cambridge: Harvard University Press; 1987. p. 126.

32. Porter R. A social history of madness. New York: Weidenfield and Nicolson; 1987. p. 62-3.

33. Andrews J, et al. The history of Bethlem. London: Routledge; 1997. p. 3-4.

34. Porter R. A social history of madness. New York: Weidenfield and Nicolson; 1987. p. 3.

35. DePorte MV. Nightmares and hobby horses. San Marino: Huntington Library; 1974. p. 108-9.

36. MacDonald M. The inner side of wisdom: suicide in early modern England. Psychol Med. 1977;7:565-82.

37. MacDonald M. Mystical bedlam, madness, anxiety and healing in seventeenth-century England. Cambridge, U.K.: Cambridge University Press; 1981. p. 112.

38. Byrd M. Visits to bedlam: madness and literature in the eighteenth century. Columbia: University of South Carolina Press; 1974. p. 116-7.

39. MacDonald M. Mystical bedlam, madness, anxiety and healing in seventeenth-century England. Cambridge, U.K.: Cambridge University Press; 1981. p. 3.

40. MacDonald M. Mystical bedlam, madness, anxiety and healing in seventeenth-century England. Cambridge, U.K.: Cambridge University Press; 1981. p. 11.

41. Porter R. Mind-forg'd manacles: The history of madness in England from the Restoration to the Regency. Cambridge; Harvard University Press: 1987. p.136.

42. Porter R. Mind-forg'd manacles: The history of madness in England from the Restoration to the Regency. Cambridge; Harvard University Press: 1987. p. 137.

43. Andrews J, et al. The history of Bethlem. London: Routledge; 1997. p. 203.

44. Porter R. Mind-forg'd manacles: The history of madness in England from the Restoration to the Regency. Cambridge; Harvard University Press: 1987. p. 138.

45. Thomas K. Man and the natural world. New York, Oxford; 1983. p. 110.

46. Mery F. The life, history and magic of the cat. London: Paul Hamlyn; 1967. p. 56.

47. Scull A. The most solitary of afflictions. New Haven: Yale University Press; 1993. p. 105.

48. Rogers KM. Cat. London: Reaktion Books: 2006. p. 62.

49. Jane Wenham entry on Wikipedia

50. Kete K. The beast in the boudoir. Berkeley: University of California Press; 1994. p. 123-44.

51. Tague IH. Animal companions: pets and social change in eighteenth-century Britain. University Park: Pennsylvania State University Press; 2015. p. 63. 
52. Bugler C. The Cat: 3,500 years of the cat in art. New York: Merrell; 2011. p. 24-5, 201.

53. Tabor R. Cats: The rise of the cat. London, BCA; 1991. p. 58.

54. Boswell J. The life of Samuel Johnson, LLD. New York: Dell Publishing; 1960; originally published in 1791. p. 330.

55. Rogers KM. Cat. London: Reaktion Books: 2006. p. 84-5.

56. Sherburne G, Bond DF. The restoration and the eighteenth century-A literary history of England. London: Oxford; 1967. p. 1075.

57. https://www.poemhunter.com.

58. Kete K. The beast in the boudoir. Berkeley: University of California Press; 1994. p. 126.

59. John NM. The uses of madness: William Cowper's 'Memoir'. Am Scholar. 34(1964-65):112-26.

60. Ella GM. William Cowper: The man of God's stamp. Dundas, Ontario: Joshua Press; 2000. p. 110.

61. Winslow HM. Concerning cats. Boston: Lothrop Publishing; 1900. p. 164.

62. Sherburne G, Bond DF. The restoration and the eighteenth century-A literary history of England. London: Oxford; 1967. p. 1076.

63. Strype J. quoted in Andrews J. The lot of the 'incurably' insane in enlightenment England. Eighteenth-Century Life 12(1); 1988. p. 1-18.

64. Andrews J, et al. The history of Bethlem. London: Routledge; 1997. p. 126.

65. Hunter R, Macalpine I. Three hundred years of psychiatry. London: Oxford University Press; 1963. p. 645, quoting William Black's "A dissertation on insanity," 1788.

66. Andrews J, et al. The history of Bethlem. London: Routledge; 1997. p. 232.

67. Andrews J. The lot of the 'incurably' insane in enlightenment England. Eighteenth-Century Life 12(1); 1988.

68. Allderidge P. Hospitals, madhouses and asylums. Br J Psychiat. 1999;134:321-34.

69. Leigh D. The historical development of British psychiatry, vol 1. Oxford: Pergamon; 1961.

70. Anonymous, An account of the rise, and present establishment of the lunatick hospital, in Manchester. Manchester: J. Harrop; 1771.

71. Digby A. Madness, morality and medicine: a study of the York Retreat 1796-1914. Cambridge: Cambridge University Press; 1985. p. 11.

72. Walker N. McCabe S. Crime and insanity in England. Edinburgh: University Press; 1968. p. 70.

73. Hunter R, Macalpine I. Three hundred years of psychiatry. London: Oxford University Press; 1963. p. 419.

74. Allderidge P. Hospitals, madhouses and asylums. Br J Psychiat. 1999;134:321-34.

75. Parry-Jones W. The trade in lunacy: a study of the private madhouses in England in the eighteenth and nineteenth centuries. London: Routledge and Kegan Paul; 1972. p. 289.

76. Moore CA. Backgrounds of English literature. New York: Octagon Books; 1969. p. 200.

77. DePorte MV. Nightmares and hobby horses. San Marino: Huntington Library; 1974. p. 57-8.

78. Small H. Love's madness: medicine, the novel, and female insanity, 1800-1865. Oxford: Clarendon Press; 1996. p 11-12. 13.

79. Andrews J, et al. The history of Bethlem. London: Routledge; 1997. p. 183-4, 6.

80. Andrews J, et al. The history of Bethlem. London: Routledge; 1997. p. 180.

81. Richardson S. Familiar letters on important occasions. Norwood, PA: Norwood Editions; 1975; first published in 1741. p. 201.

82. Webster on the study of mental diseases (review article on John Webster's observations on the admission of medical pupils to the wards of Bethlem Hospital, for the purpose of studying mental diseases). Monthly Rev. 1842;162(3):74-88.

83. Andrews J, et al. The history of Bethlem. London: Routledge; 1997. p. 186, 190.

84. Andrews J, et al. The history of Bethlem. London: Routledge; 1997. p. 183, 186.

85. Mackenzie H. The man of feeling, ch. 20. London: Oxford University Press; 1967; originally published in 1771.

86. Jamison KR. Touched with fire: manic-depressive illness and the artistic temperament. New York: Free Press; 1993. p. 292, 62-71.

87. Moore CA. Backgrounds of English literature. New York: Octagon Books; 1969. p. 231. 
88. Rousseau GS. Science and the discovery of the imagination in enlightened England. Eighteenth-Century Stud. 1969;3:117.

89. Porter R. A social history of madness. New York: Weidenfield and Nicolson; 1987. p. 94.

90. Wright T. The life of William Cowper. London: Unwin; 1892.

91. Moore CA. Backgrounds of English literature. New York: Octagon Books; 1969. p. 191.

92. Ella GM. William Cowper: The man of God's stamp. Dundas, Ontario: Joshua Press; 2000. p. 156.

93. Martin PW. Mad women in romantic writing. New York: St. Martin's Press; 1987. p. 19.

94. Small H. Love's madness: medicine, the novel, and female insanity, 1800-1865. Oxford: Clarendon Press; 1996. p. 11-12.

95. Johnson S. Lives of the English poets. Oxford: Clarendon Press; 1905. p. 337-9.

96. Kaplan LJ. Thomas Chatterton. Berkeley: University of California Press; 1987. p. 1, 17.

97. Moore CA. Backgrounds of English literature. New York: Octagon Books; 1969. p. 201, 205.

98. Moore CA. Backgrounds of English literature. New York: Octagon Books; 1969. p. 207.

99. Porter R. Mind-forg'd manacles: The history of madness in England from the Restoration to the Regency. Cambridge; Harvard University Press: 1987. p. 94.

100. DePorte MV. Nightmares and hobby horses. San Marino: Huntington Library; 1974. p. 147.

101. Byrd M. Visits to bedlam: madness and literature in the eighteenth century. Columbia: University of South Carolina Press; 1974. p. 120-1.

102. Hunter R, Macalpine I. Three hundred years of psychiatry. London: Oxford University Press; 1963. p. 351-4.

103. Viets HR. George Cheyne, 1673-1743. Bulletin History Med. 1949;23:435-52.

104. Boswell J. The life of Samuel Johnson, LLD. New York: Dell Publishing; 1960; originally published in 1791. p. 130.

105. Porter R, editor. The Faber book of madness. London: Faber and Faber; 1991. p. 113.

106. Byrd M. Visits to bedlam: madness and literature in the eighteenth century. Columbia: University of South Carolina Press; 1974. p. 94.

107. Vulliamy CE, Boswell J. Freeport, N.Y.: Books for Libraries Press; 1932. p. 269; Ryskamp C, Pottle FA (eds.) Boswell, The ominous years, 1774-1776. New York: McGraw-Hill; 1963. p. 44.

108. Hunter R, Macalpine I. Three hundred years of psychiatry. London: Oxford University Press; 1963. p. 417.

109. Anonymous. Miscellany: Dr. Samuel Johnson on insanity. Am J Insanity. 1847;3:285-7.

110. Anonymous. An account of the progress of an epidemical madness. London: J. Roberts; 1735.

111. Moore CA. Backgrounds of English literature. New York: Octagon Books; 1969. p. 193-4.

112. Hunter R, Macalpine I. Three hundred years of psychiatry. London: Oxford University Press; 1963. p. 405.

Open Access This chapter is licensed under the terms of the Creative Commons AttributionNonCommercial-NoDerivatives 4.0 International License (http://creativecommons.org/licenses/ by-nc-nd/4.0/), which permits any noncommercial use, sharing, distribution and reproduction in any medium or format, as long as you give appropriate credit to the original author(s) and the source, provide a link to the Creative Commons license and indicate if you modified the licensed material. You do not have permission under this license to share adapted material derived from this chapter or parts of it.

The images or other third party material in this chapter are included in the chapter's Creative Commons license, unless indicated otherwise in a credit line to the material. If material is not included in the chapter's Creative Commons license and your intended use is not permitted by statutory regulation or exceeds the permitted use, you will need to obtain permission directly from the copyright holder. 